\title{
MÁRIA TERÉZIA PÁTENSEI A HADIROKKANT ELLÁTÁSRÓL - 2. RÉSZ
}

\author{
Szerzők: \\ Mihók Sándor (Dr. Jur.) \\ nyugalmazott jogtanácsos \\ Fejes Zsolt (PhD) \\ Magyar Honvédség Egészségügyi Központ \\ Helyes Marcell \\ Karl-Franzens Universitat (Ausztria) \\ Első szerző e-mail címe: \\ sakinew@hotmail.com
}

\section{Lektorok:}

Kóródi Gyula (Prof. Dr.)

Nemzeti Közszolgálati Egyetem

Rikk János (PhD)

Kodolányi János Egyetem

...és további két anonim lektor

\begin{abstract}
Absztrakt
Cikksorozatunk második részében a Pesti Invalidus Ház történetét tekintjük át 1751-tôl az 1783-ban történt megszűnésig, különös tekintettel a rokkantrendelet 1772-ben történt revíziójára. A cikk folytatásában betekintést nyújtunk a rokkant katonák rendhagyó életpályájába, valamint az „újrahasznosított” hadirokkantak kalandos hétköznapjaiba. Végül bemutatjuk, hogy a pátens második kiegészítése milyen hatással volt a 19. század végének magyar hadigondozására és katonaegészségügyére.
\end{abstract}

Kulcsszavak: hadigondozás, hadirokkant otthon, rokkantellátási rendelet

Diszciplínák: történelem, orvostudomány, hadtudomány

\section{Abstract \\ MARIA THERESLA'S PATENTS ON THE PROVISION OF BENEFITS TO DISABLED VETERANS - 1ST PART}

In this second part of our series, we will review the history of the Invalids' Home in Pest from the year 1751 to 1783 (when it was closed), with special emphasis on the 1772 revision of the Disability Decree. Furthermore, we will provide readers with an insight into the unorthodox careers of disabled soldiers, and into the eventful daily life of the „recycled” disabled veterans. We will show how the patent's 2nd amendment impacted on military nursing and military medicine of late 19 th century Hungary.

Keywords: military nursing, home for disabled veterans, decree on the provision of benefits to the disabled

Disciplines: history, medicine, military science 
Mihók Sándor, Fejes Zsolt és Helyes Marcell (2021): Mária Terézia pátensei a hadirokkant ellátásról - 2. rész. Lélektan és hadviselés - interdiszciplináris folyóirat, III. évf. 2021/1. szám. 23-36. doi: 10.35404/LH.2021.1.23

\section{A Pesti Invalidus Ház története 1751-től a megszüntetésig}

Amikor 1751 augusztusában Mária Terézia meglátogatta a Pesti Invalidus Házat, állítólag így nyilatkozott: „,szebb, mint a Burg!” Kazinczy Ferenc pedig „Királyi Mívnek” nevezte a nagy, komoly hangulatú, múvészi megjelenésű palotát.

Érdekes volt a háromemeletes épület lakóosztályainak egykori elrendezése is. A boltozott folyosókra a fóhomlokzaton előszobáskonyhás utcai kétszobás: ún. „tiszti lakosztályok" nyíltak, az oldalsó szárnyak négy ablaktengely széles, négyzetes alaprajzú részekre oszlottak, közepüket egy nagymélységű kétablakos lakóterem foglalta el, attól jobbra és balra egy külső és belsô szoba között konyhák foglaltak helyet. Egy-egy szoba négy rokkant, vagy egy családos rokkant számára szolgált. E helyiségek félemelet magasak voltak és felettük további négy szoba helyezkedett el, amelyekhez a folyosóról két kis csigalépcső vezetett. Egy-egy ilyen lakosztályban tehát 32 rokkant talált menedéket (Bierbauer, 2004).

Mária Terézia uralkodása idején a Pesti Invalidus Házban külön lakrész jutott a betegeknek, külön a bolondoknak (a tébolydát egyébként „Corruptenhausnak” hívták), és külön lakosztály az Úristennek.
1765 februárjában az uralkodó megbízta Franz Anton Hillebrandt kamarai építészt, hogy az építsen az Invalidus-templomban új főoltárt, továbbá emeljen a megszaporodott elmebeteg invalidusok számára negyven szobából álló tébolydaépületet, amely a városfalon kívül a félrondella és a Rostély utcai kijáró között zárt belső udvarral csatlakozott az irgalmasok vezette kórházi szárnyépülethez. Lásd: Schoen (1930, 108. o.).

A templomban vasárnap és ünnepnapon Mária Terézia külön rendeletére - a nagymisét a pesti ének- és zenekar kísérte (Molnár, 1969). 1752 márciusában a királynő Bécsből egyházi ruhákkal együtt 24 darab fából faragott és aranyozott gyertyatartót és 8 fafeszületet adományozott a templomnak. 1762-ben azonban már úgy rendelkezett, hogy ,,a templom fölszerelése lehetőleg Pesten szereztessék be". Azonban egészen haláláig kiemelt figyelmet fordított a rokkant katonák lelki üdvösségére, a templom felszereléseire és azok folyamatos karbantartására. Az idős uralkodó tervei között szerepelt, hogy az elhunyt katonák részére a templom kriptájában halotti fülkéket létesít. Halála után az Invalidus Ház vezetôsége megbízást adott 400 fülke építésére, 
azonban 1781-ben csak 100 fülke került átadásra, mivel a pénzforrások - végleg - elapadtak (Schoen, 1930).

Mária Terézia idején az Invalidus Ház lényegében állam volt az államban. Falai között bolthálózat múködött, saját manufaktúrái és iskolái voltak. A kantinjában pedig még csempészett sört is mértek... Saját pénze volt, természetesen a kétfejű császári sassal díszítve, amelyet ,xenodoch”-nak neveztek (1. ábra).

1. ábra: A Pesti Invalidus Ház réz 3 krajcárosa. Forrás: Net1
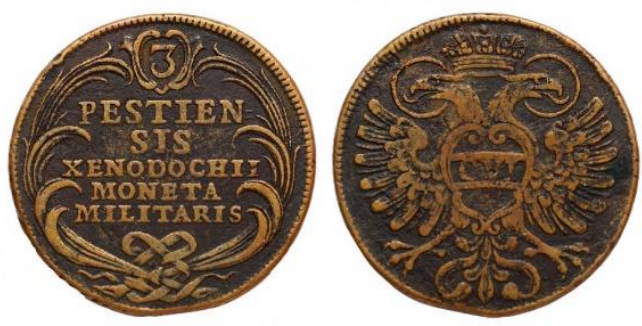

Az Invalidus Ház messzemenően gondoskodott lakóiról. Egy hadnagy például évente 150 forintot kapott, másfél mázsa túzifát, 60 font gyertyát, 30 font sót és naponta négy porció kenyeret. A közlegény ezzel szemben nem forintban kapta a fizetését. Naponta három xenodoch illette meg, egy lat (kb. 2 dkg) só és egy adag kenyér, de ezen kívül ruhát is kapott. A mundérnak azonban, a reglama szerint legalább egy esztendeig kellett tartania.

II. József trónra lépésével a rokkantak „talmi aranykora" véget ért. A császár néhány tollvonással megszüntette az intézményt (Molnár, 1969). Természetesen az intézkedést nem a rokkantak iránti ellenszenv, hanem szigorú gazdasági megfontolások indokolták. Az ural- kodó - országos tiltakozást kiváltó - takarékossági intézkedései között szerepelt például az is, hogy az úrvacsorán csak két gyertya világíthat, vagy a halottak koporsó nélküli, vászonzsákban történő eltemetése és klórmésszel történő leöntése azért, hogy ez minél kevesebb termőföld használattal járjon stb...

Ezért sem meglepő, hogy az uralkodó a szerzetesrendeket azért törölte el, mert szerinte: „henyélnek, és nem dolgoznak” (Pezenhoffer, 2004, 314. o.).

A fentiek alapján így egyértelmű, hogy a Pesti Invalidus Ház miért nem kerülhette el a sorsát. 1783. július 10-én kelt pozsonyi „Handbillet”-jével az uralkodó a rokkantakat Nagyszombatba telepítette, az épületet pedig gránátos laktanyává alakíttatta. Templomában ispotályt rendeztetett be, a kegyszereket pedig - a korszakban egyedülálló módon - elárvereztette (Molnár, 1969).

1784. július 27-én a templomlomot megfosztották vallásos rendeltetésétől, vagyis „exsecráltatott”. A templomi tárgyak értékesítését az újságban közhírré tették. Július 28-án zajlott a nyilvános árverés, amelynek bevételét a gránátos kaszárnya kápolnája kapta. Érdekesség, hogy a gránátosok parancsnokának, Degenschild alezredesnek a neje is vásárolt egy oltárképet. Lásd: Schoen, 1930, 108. o.

A kripta 68 halottját is kihantolták és helyüket gyapjúbálák(!) foglalták el. Amikor Alvinczy generális a gránátos laktanya költségvetését a császár elé terjesztette, II. József csak 
ennyit írt az aktára: „placet!” és az Invalidus Ház ügyét ezzel végleg lezárta. Ettől kezdve az épületet 100 éven át Károly-kaszárnyának hívták (Molnár, 1969).

A fentiek alapján ugyanakkor meglepő, hogy Magyarország területén az első állandó katonai egészségügyi intézmény alapítását II. József rendelte el de, csak azért, mert azt ésszerűnek és rendkívül hasznosnak tartotta. „A Cs. Kir. Pesti Helyőrségi Kórház elnevezésű intézmény bizonyíthatóan 1785-től kezdte meg mûködését” (Kiss, 2003, 16. o.). A kétemeletes kórház emeletén nyolc-nyolc kórterem, a földszinten a gyógyszertár, az orvosok és a személyzet lakásai kerültek kialakításra (2. ábra). Volt szülőszobája a katonatisztek feleségeinek és négykádas fürdőszobája, amely ritkaságszámba ment abban az időben (Budai Napló, 1937.04.22, 16. szám, 6. o.).

2. ábra: „Magosabb rangú katonaorvos és egy invalidus a 18. század végén és a 19. század elején". Forrás: Magyary-Kossa (1940, 146. o.)

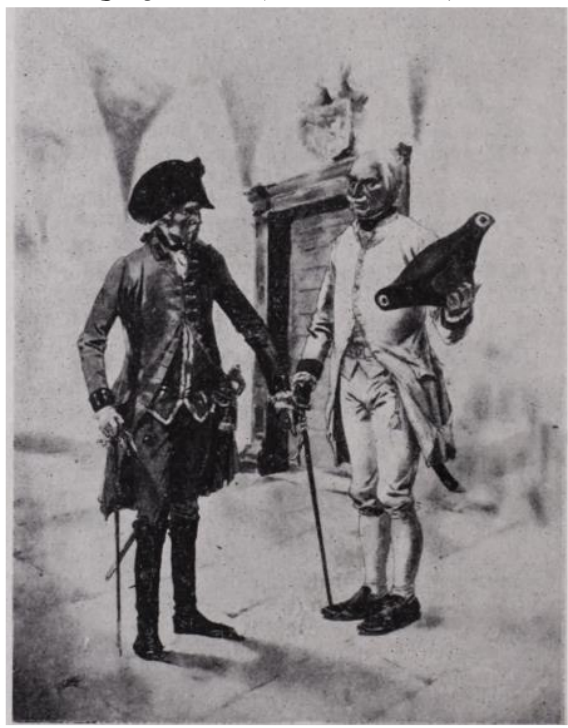

A kalapos király halála után azonban bebizonyosodott, hogy a Pesti Invalidus Ház lakóinak elköltöztetése nem volt gazdaságilag kellően megalapozott döntés, azt kizárólag az állami kiadások csökkentése indokolta.

A rokkant katonák ellátása - továbbra is - sokba került az adózó polgároknak. A Nagyszombati Invalidus Házban elhelyezett katonák ellátásával kapcsolatban egy 1791-ben kelt jelentés arról számolt be, hogy száz szekér élelmet és lisztet szállított nekik a járási biztos, vagyis a fenntartási költségeket az állam nagyvonalúan a megyére hárította. Lásd: Tamáska (1994, 40. o.).

A Pesti Invalidus Ház épületének oromattikájának mára teljesen eltűnt szobrai közül a középső csoport Schoen Arnold mûvészettörténész szerint jelképes tartalommal bírt. A szoborcsoport üzenete az volt, hogy: „, . az invalidusház létesítését, melyet bőségből származó adakozás útján gyűjtött pénzből emelt az építész, az uralkodónak katonái iránt lobozó szeretete mozdította elő, amely szeretet a hála koronájával őrködik a benne lakók fölött” (Budapest Városháza Fórum Tervpályázat, Műemlékvédelmi Tervfejezet, 1. o.). Természetesen a homlokzat bal és jobb oldalán álló szoborcsoportok is allegorikus tartalommal bírtak. 
A jobboldali szoborcsoport két-két figurája „... közül balról jobbra haladva az első a katonai éberséget jelképező sisakos nő jobb kezével a mellette egy lábon virrasztó darumadárra mutat, a másik kezében iránytűt tart. Párja, a hadigondozást jelképező nő jobbjában bőségszarut, bal kezében pedig római congiariumot tart. A harcból megtért katonát jelképező nő jobb kezével vértezetét oldozza le, baljával kardra támaszkodik, bal lábával pedig bombára tapos. Párja, a negyedik női alak cintányérral méheket hív a jobb lábánál lévő kaptárba, amely a katonai menhely jelképe. (...) A négy alak együttes értelmezése szerint az erős, fiatal katonát ravasz óvatosság vezeti ellenfele leterítéséhez és a győzelmi jutalomhoz, a veterán katonát pedig a harci dicsőség pálmája és koszorúja várja” (Hámori, 2014, 34. o.).

Az uralkodói szeretet és hála - a szobrokhoz hasonlóan - eltűnt, de az épület a mai napig maghatározó barokk építészeti emléke maradt hazánknak.

\section{A rokkantrendelet revíziója}

A költségek további csökkentése céljából 1772-ben egy újabb rokkantellátási rendszert vezetett be az uralkodó. Az új rendszer előírásai alapján csak a teljesen munkaképtelen tisztek, altisztek és közkatonák tarthattak igényt a rokkantházakban történő ellátásra. A „kevésbé munkaképteleneket” könnyebb helyőrségi, raktári stb. szolgálatra alkalmazták, itt teljes ellátást és ezért kisebb nyugdijat is kaptak.

A rokkantak minden hó elsején a tartózkodási helyük pénztáránál vehették fel a nyug- dijukat és azért, hogy visszaélések ne forduljanak elő, pontos nyilvántartást kellett róluk vezetni és ezeket évenként a Hadbiztossági Hivataloknak elküldeni, valamint az előforduló halálozásokat is azonnal bejelenteni.

$\mathrm{Az}$ 1750. évi rendelethez hasonlóan, az új szabályozás is megengedte, hogy a teljesen rokkantak a rokkantházakon kívül is élhessenek. A nem teljesen rokkantaknak is megengedték az otthonlakást. Ezek az ún. „pátenses rokkantak" a nyugdíjon kívül szülőhelyükön ingyen lakást, fütést és világítást kaptak, de a nyugdíjról le kellett mondaniuk és ezért csak akkor kaptak erre engedélyt, ha otthonukban biztosítva volt a megélhetésük.

Sokan azonban, akik leküzdhetetlen ellenszenvet éreztek a rokkantházi élettel szemben - bár megélhetésük otthon nem volt biztosítva, mégis - kérelmezték e jogcímen történő hazabocsáttatásukat, amelyet legtöbbször a hatóságok engedélyeztek. Otthon azonban ezt követően nyomorogtak, lakóhelyüknek csak terhükre voltak.

Azért, hogy ez a jövőben elő ne forduljon, a Haditanács elrendelte, hogy a legközelebbi rokkantszemle alkalmával minden rokkantnak igazolnia kell, hogy a megélhetése biztosítva van, még pedig a magyarok azzal, hogy van otthon földjük, az idegenek pedig, hogy gyáraknál, iparosoknál vagy magánosoknál állandó alkalmazással bírnak. Ellenkező esetben a honiakat el kellett helyezni a rokkantházakban vagy helyőrségeknél, a külföldieket pedig, ha gyermekeik voltak, le kellett telepíteni, ,hogy ők és utódaik a monarchia hasznos tagjai legyenek", ha pedig gyermektelenek, kellő útiköltséggel ellátva, hazájukba küldték őket vissza (Pelz, 1916, 377. o.). 


\section{„Újrahasznosított” rokkantak, rendhagyó életpálya a rokkant katonáknak}

Mária Terézia uralkodásának idején a koronaőrség megkezdte betagozódását a reguláris haderőbe. Az 1751. évben a Pesti Invalidus Ház félrokkant gránátosaiból két századot szerveztek koronaőri szolgálatra, akiket Pozsonyba vezényeltek. Az alakulatnak Mária Terézia a „Magyar Királyi Koronaőrség” nevet adta.

A rokkant vitézek a korona őrzése tekintetében a két koronaôr fóúrnak, katonai szempontból az udvar rokkantügyi bizottságának és a legfelsőbb haditanácsnak, az ôr és belsőszolgálat viszonylatában pedig a pozsonyi várkapitánynak voltak alárendelve. Ebben az évben a koronaőrség számára szolgálati szabályzatot adtak ki. A gránátosok kijelölése erre a feladatra az alakulat egyfajta reprezentatív, díszelgő jellegéról árulkodott. Az 1608-ban létrehozott koronaőrcsapat ugyanis még nem a reguláris haderő része volt, így a ruházatuk sem ismert, azonban a reguláris haderô részét képező, 1751-ben alapított koronaőr alakulat gránátos egyenruhájáról már részletes dokumentáció lelhető fel (Net2).

„1784-ben Mária Terézia fia, II. József (1780-1790) feloszlatta a koronaőrséget, de később II. Lipót (1790-1792) visszaállította a szervezetet. A magyar Szent Korona ôrzésével foglalkozó - 1715-ben és 1790-ben keletkezett - törvények Budát jelölték ki őrzési helyül és rögzítették a váratlan események, illetve veszély esetére a teendóket" (Pálmai, 2012, 212. o.).

A kevésbé szerencsés rokkant vitézek ennél jóval szerényebb „második életpályát” futottak be.
A tömlöcrendszeren éket ütni hivatott és viszonylag rövid életú „,magyar fenyítőház”: a „Domus Correctoria” története (is) szorosan kapcsolódik a hadirokkantak magyarországi történetéhez.

Az 1772-ben Szempcen megnyílt, majd 1780-ban Tallósra költöztetett és pályafutását végül a szegedi vár kazamatáiban dicstelenül befejezett Domus Correctoria esetében a hadsereg állományából beosztott ôröket 1793-tól a rokkant katonák (!) váltották fel. Ugyanis egy 1793. január 18-án kelt helytartótanácsi leirat elrendelte, hogy „patentális rokkant”, vagyis leszázalékolt katonák lássák el a továbbiakban a felügyeletet. Nyilvánvaló, hogy a hadsereg így igyekezett megszabadulni a terhes feladattól és öreg obsitosait f́gy próbálta meg „rásózni" a dologházra.

A korabeli jelentések tanúsága szerint a vagyontalan, otthontalan, rokkant vagy kiszolgált katonákkal legalább annyi ügyes-bajos gond adódott, mint magukkal a rabokkal. 1793-tól 1804-ig az ôrség a javítóházban az első osztályból, tehát a teljesen erőtlen és nyomorult kivénhedt hadfiakból állt. Átmenetileg néhány évig felbukkantak az őrségben félrokkantak is. Szabó Gergely igazgató 1800-ban kelt jellemzése szerint: „ez a ház a kimondhatatlan rendetlenség és az elvénült katonák miatt, kik szakadatlan ivásnak adták magukat, olyan állapotba jutott", mely immáron alig orvosolható. Az új direktor, Rott József listát állított össze az őrök alkalmasságáról (pontosabban alkalmatlanságáról). Eszerint közöttük vannak 72 és 85 éves, 65 esztendeje szolgáló, második gyermekkorukat élő obsitosok, 60-as éveik végét taposó járóképtelenek, italozás közben megnyomorodottak, a káplár parancsának nem engedelmeskedők, legtöbbjük 
pedig részeges, ellenszegülő, rendszeresen kihágó személy. A fenti személyzet - nem ritkán káplárjuk vezetésével - a szegedi kocsmai verekedések állandó résztvevője volt: büntetőeljárások indultak civil személyek bántalmazása miatt; a városi munkára kirendelt rabokkal a kísérő őrök együtt részegedtek le, sôt az is előfordult, hogy ittas állapotban ôr és rab együtt rontottak az őrség józanabb felére.

Sokatmondó a fegyelmi eljárásokat tartalmazó kimutatás, miszerint az őrök által elkövetett gyakoribb kihágások az italozás, a szolgálat elhanyagolása, az őrhelyen való alvás, rab részére pálinka becsempészése, sikkasztás, lopás, éjjeli - engedély nélküli - elkóborlás, szökés.

A helyzet kialakulásában nyilván közrejátszott, hogy a kiszolgált öreg katonák megbecsültsége semmilyen értelemben nem volt rendezett. Jelképes javadalmazásuk valóban alig futotta többre a kocsmai italozás fedezésénél. Az évi 48 forint 40 krajcár mellett a rabokénál alig jobb minőségú hálótermek álltak rendelkezésükre. Adalék a zsold, illetőleg egyenruhapénzt magában foglaló összeg értelmezéshez: a disznóhús fontja 30 krajcárba került, a szalonnáé 54-be, a vajé 1 forint 30 krajcárba. Ezzel szemben egy icce sör 12, ugyanannyi bor pedig 24 krajcár volt csupán. Egy lényeges észrevétel, hogy hosszú ideig még kenyeret sem kaptak (!) az ôrök az intézettől ételük mellé, ezért 1812-ig gyakorlatilag teljes zsoldjuk a kenyér vásárlására folyt el.

A Helytartótanács 1814-ben némi hajlandóságot mutatott a rokkantak lecserélésére és azok felváltására rendes katonai állománnyal. Amikor azonban kiderült, hogy a szegedi vár kazamatáiba telepített fegyintézetnek nincsen megfelelő elszállásolási lehetősége, a döntést felfüggesztették. Ezt követően az intézet feloszlatásáig (1832) a helyzet változatlan maradt (Mezey, 1993, 51-57. о.).

A Domus Correctoria eredeti utasítása szerint: az intézet egyben rabdolgoztató ház is volt, ahol szalmazsáknak való vásznat, gabonás zsákokat, katonai foszlánynak való csinvatot, lópokrócokat állítottak elő, amelyben jól felismerhető a biztos felvevőpiacra, az állami vásárlóra: a katonaságra építő elgondolás.

A többnyire érdekeltség nélkül dolgozó rabok munkája olyan silány volt, hogy a megrendelők rendre nem vették át a roszszul festett, mocskos árut. Koppel Jeremiás óbudai kereskedő 1778 decemberében például a leszállitott 1000 pokrócból egyetlen egyet sem vett át minőségi, méret és tisztasági problémák okán (Mezey, 2018, 378-379. o.). Ez azért is érdekes, mivel Koppel csak a katonaságnak dolgozott, áruját a jó minőségű, olcsó posztót és pokrócot a Pesti Invalidus Házba (!) szállította (Nagy, 1975, 109. o.).

Említést érdemel, hogy Erdélyben 1787. január 1-jétől működött a szamosújvári tartományi (provinciális) börtön, amit - a katonai várból - II. József 1786. március 27-i udvari rendelete alapján szerveztek börtönné. A szamosújvári börtön felügyeletét és igazgatását az erdélyi főkormányszék látta el. „A börtön elöljárósága ebben az időben a következő volt: egy várnagy, egy írnok, egy őrmester, egy takarítószolga és 24 tartományi őr. Az utóbbiakat a katonai szolgálatból kilépett, félrokkant katonákból is fel lehetett fogadni." (Estók, 2019, 11. o. hivatkozik Megyery, 1905 művére). 


\section{A rokkant tisztek és közkatonák}

\section{sorsa a napóleoni háborúktól 1875-ig}

A francia háborúk példátlan erőfeszítéseket követeltek a hatalma megtartásában alapjaiban veszélyeztetett bécsi udvartól. A Habsburgok és a magyar nemesség szövetsége szükségszerűen teremtődött meg: a francia eszmék, a kiváltságok eltörlésével és a társadalom polgári átalakulásának hirdetésével, trónt és előjogokat egyaránt fenyegettek.

A hatalmas anyagi és véráldozattal járó sorozatos küzdelemből Magyarország alaposan kivette a részét: a többszöri újoncozás következtében a magyar csapatok létszáma megközelítette a 200 ezer főt. A háborús részvétel másik formája a nemesi felkelés volt, melynek hadba hívását a birodalmat sújtó hadiesemények többször is szükségessé tették. Az újra életre hívott inszurrekció korszerūtlensége akkor bizonyult be - végérvényesen és látványosan -, amikor a napóleoni háborúk során 12 éven belül négyszer is fegyverbe szólították.

E háborúkat korábban nem ismert hatalmas létszámú hadseregek vívták, melyeknek veszteségei is tetemesek voltak. Az utánpótlás, a hadsereg-kiegészítés megszervezése egyre nagyobb és sürgetőbb feladat lett. Ez az európai államok többségét előbb-utóbb új, egyre inkább az általános hadkötelezettség felé vezető, francia mintájú hadkiegészítési rendszerek bevezetésére kényszerítette.

A társadalmi viszonyok ellenállóképessége gyengítve az állam védelmi erejét - helyenként még elég erősnek bizonyult a szükséges újítások elhárítására. Ennek jellegzetes példája az „önmagát túlélt” inszurrekció története is. A napóleoni háborúk nemesi felkelései során 1797 és 1809 között - közel 135.000 embert mozgósítottak (Ódor, 1989). A Habsburg-birodalom tisztjei a napóleoni háborúk idején álltak tekintélyük csúcspontján, azonban a fizetésük szinte ekkora érte el a mélypontot. Az állam katasztrofális pénzügyi állapota miatt a tisztek helyzete 1851-ig, a zsoldreformig nem változott. Ráadásul a meghatározott illetmények összege tartományonként és fegyvernemenként rendkívül különbözően alakult. Ebben az időben ezért a tiszti pálya vonzerejének egyik leglényegesebb eleme a „nyugdí)" volt.

A Habsburg-birodalom hadseregében a 19. század közepéig ismeretlen volt az intézményes nyugdíj fogalma, a tisztek addig szolgáltak, amíg bírtak. 1777-ben Mária Terézia bevezetett egy olyan „méltányossági” alapon nyugvó nyugdíjrendszert, ami a rokkantsági fokon alapult. Ekkor a nyugdíj még semmilyen összefüggésben nem állt a szolgálati idővel (Závodi, 2012).

De térjünk át a háborúk áldozataira, akik nem csak a harcmezőn elesett vagy betegségben elhunyt katonák voltak. A napóleoni háborúk idején ugyanis a közkatonák katonai szolgálata meghatározatlan ideig (általában 3035 évig) vagy az obsitlevél kiállításáig tartott. Ezért az obsitlevél és az obsitos katona már több száz éven át élő, elterjedt fogalmi eleme a magyar közgondolkodásnak.

Az „obsit” szó eredete könnyen azonosítható a német nyelvben elterjedt, bajorosztrák eredetű „Abschied” kifejezéssel, amely búcsút, elbocsátást jelent. A szó első felbukkanása a Magyar Történeti-Etimológiai Szótár szerint 1655-höz kötődik, s már ekkor átvitt értelemben használják. 
A 18. század 70-es éveitől gyors egységesülésnek és intézményesülésnek lehetünk tanúi: a személyes adatokon kívül a szöveg nagy része előrenyomott, némi művészet kizárólag az iniciálé-szerű első betúk vagy sorok elrendezésében, illetve esetenként a papírfelzetes pecsétekben lelhető fel.

1830-ra az irat középső részén megjelenő osztrák császári címer állandó motívummá vált. Lásd: Szoleczky, 2001, 202 203. о.).

A hazatérő obsitosok azonban hatalmas gondot jelentettek a társadalomnak. Azok az ígéretek, melyek bevonulásukkor hangzottak el, hazatértükkor már semmivé váltak.

Az országgyűlés 1807-ben, 1830-ban és 1840-ben hozott végzései szerint az obsitosoknak: „...a következő kedvezmények adassanak, úgy, mint: hogy a fejadó személyes terhe, valamint a közmunka, út, töltés és hidak építése és javítása, úgy szintén a hivatalos levelek szállítása alól is felmentve legyenek. Olly helyen, ahol társas házak vannak, valami munka vagy mesterség fejében mindenütt ingyen fogadtassanak be; ezek a kedvezmények, továbbá a rokkantakra, feleségeikre, sőt mindkét nembeli gyermekeikre is, olykép terjesztessenek ki, hogy az illy gyermekek árva és szegényházakba...első sorban vétessenek fel...." Megjegyzést érdemel, hogy 1807-ben a törvény húszéves katonáskodás, majd rokkantság esetén adta meg ezeket a kedvezményeket, addig az 1840-es törvény elaggott, vagy hosszas szolgálat által eltörődött katonákról beszél (Balogh, 1983).
Az öreg közkatonák közt volt ugyan néhány talpraesett ember, aki tisztesként vagy őrmesterként karriert csinált, esetleg otthon - különösen a huszárok közül - az uradalomban lovászként, lovászmesterként tette hasznossá magát, kamatoztatta ismereteit. A kevésbé szerencsés obsitosnak, ha volt családja és viszszafogadták, akkor szerencséje volt, gyakran azonban csak perpatvar árán tudott magának némi életteret biztosítani. A birtok urai nemegyszer örömmel fogadták őket, mert a katonaviseltség nem csak azért volt előírás az alkalmazásnál, hogy az uradalmak, gazdaságok és falvak gyakorlott embereket kapjanak, hanem azért is, mert ezek a katonaságnál megszokták, hogy fegyelmezetten és ellentmondás nélkül kell teljesíteni minden utasítást és parancsot.

A háborúból hazatért obsitos katonák legkiszolgáltatottabb csoportja az invalidusoké, a hadirokkantaké volt. Betegen, „csonkán-bonkán”, szemük világát vagy hallásukat elveszítve vergődtek haza szülőföldjükre, de rendszerint senkinek sem kellettek. Amennyiben nem voltak vagyonos hozzátartozóik odahaza, akik eltartották őket, egyébként koldulásból, kegyelemkenyéren, szánalomból adott megalázó segédmunkából, alkalmi keresetből tengették szánalmas életüket.

A korszakban számos jogi eljárás indult, amelyek tárgya az volt, hogy a bevonult katonát vagyonából kiforgatták. Az ilyen csalárdságoknak eleve elejét vették az 1807-ben, 1830-ban és az 1840-ben keletkezett törvények azzal, hogy kimondták: „,... Az újoncok odahaza hagyott vagyonára illendő gond legyen ... javaik ... azonnal összeírassanak ... s ingyen az árvák dolgaira rendelt polgári intézet felügyelése alatt tartassanak ..." (Balogh, 1983, 12. о.). 
Az állam egészen csekély évi összeget biztosított számukra, amiből egyszerūen képtelenség volt megélni. Haláluk után még maradék katonai köpenyüktől és zubbonyuktól is megfosztották holttestüket, hogy azokat kötelező módon a katonai raktárba szolgáltassák be a hozzátartozók. A napóleoni háborúk után fél esztendővel a hadirokkant közlegények kérdése annyira súlyossá vált, hogy a központi hatóságok átfogó intézményes megoldásra gondoltak, annak terhét azonban a területi szervekre igyekeztek hárítania.

A probléma súlyosságát igazolja, hogy a hosszas háborúk nyomán a birodalomban 50 843 hadirokkantról kellett gondoskodni; ezért az uralkodó további invalidusházak létesítésére szólította fel a törvényhatóságokat. Ebben az időben 6702 rokkant invalidusházakban élt, 19 060-at otthon tartottak el, azonban 25081 invalidus társadalmi segítségre szorult (Csetri, 1999). Ezért 1817-ben az udvari haditanács „a legénységi létszámhoz tartozó személyeknek rokkantsági zsolddal való ellátására" egy szabályzatot adott ki, amelyet az elkövetkező évtizedek során rendeleti úton többször módosítottak. A közös hadsereg és haditengerészet tisztjei, lelkészei, katonái, hivatalnokai és egyéb hópénzes egyénei nyugdijaztatása pedig egy 1855-ben kiadott nyugdijszabály alapján történt (Net3).

\section{Összegzés}

Mária Terézia hadirokkant ellátási pátensének második kiegészítése, még egy évszázaddal később is meghatározta a hadirokkantak ellátásának alapelveit. A közös hadsereg (hadi tengerészet) és a magyar királyi honvédség egyéneinek katonai ellátásáról szóló
1875. évi LI. törvénycikk - a katonai ellátási törvény - átvette az uralkodó rokkantellátásról vallott „hitvallását”: a hálát és az ésszerű takarékosságot. A katonai ellátási törvény ugyanis a megbecsülés jeléül, a rokkant katonák számára nyugdijat és sebesülési, illetve személyi pótdíjat állapított meg járadék formájában és nem kegydíjat vagy szegénysegélyt. A járadékellátás bevezetésével az volt a törvény fô célja, hogy a rokkantakat a szegénysegélyezéstől megóvja továbbá az, hogy számukra méltó módon egy „létminimumot” biztosítson (Melly, 1932). A katonai ellátási törvény ezért lehetővé tette, hogy az állandó nyugdîjban részesülő rokkant tisztek rokkantházi elhelyezésben részesüljenek.

A rokkant altisztek és a közkatonák számára a katonai ellátási törvény a tiszteknél - alapesetben - szigorúbb feltételekhez kötötte a rokkantházi elhelyezést. Az igényjogosultsági feltételek között szerepelt a legalább harminc év megszakítás nélküli tényleges szolgálat. „Az ellenség előtt történt megsebesülés”, vagy a katonai szolgálatban szemük világát elvesztett katonák, vagy azok, akik olyan súlyosan sérültek meg, hogy különös ápolásra és felügyeletre volt szükségük - az előírt szolgálati időtől függetlenül - jogosultak voltak az elhelyezésre. Továbbá azok a közkatonák is igényjogosultak voltak ,a rokkantak valamely házába való fölvételre", akik a tényleges szolgálat közben elmetompultságba (pszichés zavarok gyűjtőfogalma) vagy „nehéznyavalyába” (epilepszia) estek, vagy szélhüdés (agyvérzés) következtében magatehetetlenekké váltak és rokonaiknál a kellő ápolásban nem részesülhettek (Katonai ellátási törvény: 47-58.§, 99105.§). 
A rokkantházba felvetteket az ellátáson felül még zsold is megillette, ha pedig az ellátás helyett nyugdíjat vettek igénybe, továbbra is nyitva állt előttük a rokkantházba való visszatérés lehetôsége. Természetesen a férőhelyek korlátozott száma miatt a hadügyminisztérium csakis azokat utalta be, akiknek más módon való elhelyezése nem sikerült (Melly, 1932).

Az 1876-ban kiadott, a katonai ellátási törvény végrehajtásáról rendelkezô utasítás - a takarékosság jegyében - már kifejezetten rendelkezett arról, hogy még mielőtt az eltompult, nehéznyavalyás vagy szélhűdéses magatehetetlen katonákat felülvizsgálat alá vonnák: „annak családi viszonyai a legszorgosabban kipuhatolandók a végből, vájjon az illetô nem találna-e szükséges ápolást övéinél: s az eredmény a felülvizsgálati eljárásnál ... megfelelő módon felhasználandó.” - Utasítás a közös hadsereg (haditengerészet) és a $\mathrm{m}$. kir. honvédség egyéneinek katonai ellátásáról szóló 1875. évi LI. törvényczikk végrehajtása tárgyában (Rendeleti Közlöny a Magyar Királyi Honvédség számára, „A törv. cz. 99-ik §-hoz”, Rendeleti Közlöny a Magyar Királyi Honvédség számára, 1876 (3. évfolyam, 1. szám).

Mária Terézia a Pesti Invalidus Ház mellett még egy - szerényen felszerelt és kis létszámú személyzettel ellátott - tébolydában helyezte el az elmebeteg katonákat. Egy évszázaddal később pedig már arról rendelkezett egy miniszteri szervi határozvány, hogy a „Rokkantház-kórház Nagy-Szombaton” intézet alárendeltségében egy külön berendezett „katonai tébolyda" múködjön. A katonai rokkantházak kórházai pedig ettől kezdve az ,állandó egészségügyi intézetekhez" tartoztak és a csapatkórházakkal azonos státusszal rendelkeztek
(„Ministeri szervi határozvány” IV., Rendeleti Közlöny a Magyar Királyi Honvédség számára, 1883 17. szám, 26.).

Véleményünk szerint, Mária Terézia hadirokkant ellátásról szóló pátensei - összehasonlítva a korabeli európai államok hasonló rendelkezéseivel - elveiben korszerű és gyakorlatban is végrehajtható rendelkezések voltak. Ezt alátámasztja, hogy ebben az időben egyes kisebb államok, például az AnhaltZerbst hercegség, a waldecki hercegség, a brandenburg-ansbachi őrgrófság és - különösen - a hesseni őrgrófság egyik fő bevétele a katonai szolgálatra alkalmas fiatal férfiak értékesítése volt, amelynek „,piaca” az északamerikai gyarmati háborúban súlyos emberhiányban küszködő Anglia volt. A közel 20 ezer „értékesített” hesseni katonából csak 12 ezer fő tért vissza szülőföldjére, azonban a sérült, beteg katonákról az uralkodó egyáltalán nem gondoskodott. A 18. századi emberkereskedelem roppant kegyetlensége még Friedrich Schiller: Ármány és szerelem című 1783-ban megjelent drámájában is ábrázolásra került (Ráth-Végh, 1977, 146-147. o.).

Mária Terézia hadirokkant ellátási rendeletének korszerűségét továbbá alátámasztja az a tény is, hogy még a Habsburgok ősi ellensége, Franciaország is csak 1793. június 24-én foglalta először törvénybe a fogyatékosok eltartáshoz való jogát. Ekkor született meg ugyanis az első törvény, amely a társadalom feladatává tette a fogyatékosok ellátását (Weinhoffer, 2017, 23. o.). Franciaországban a fogyatékosok közzé sorolt rokkant katonák - akik a Napkirály halála után lényegében a feledés homályába vesztek - csak a 18. század legvégén, a győztes háborúk idején kerültek ismét a társadalmi érdeklődés középpontjába. 
A francia győzelemmel záruló első koalíciós háborút követően 1797. június 22-én Bonaparte Napóleon tábornok így nyilatkozott a rokkant katonáiról (Carrieu, 2014, 317. o.): „Ezek a bátor emberek hozzájárultak a Köztársaság hadseregének dicsőségéhez."

\section{Irodalom}

Balogh Gy. (1983): Újoncállitás Heves megyében a francia báborúktól 1847-ig - Tanulmányok Heves megye történetéböl 7. Heves Megyei Levéltár, Eger

Bierbauer V. (2004): A magyar épitészet története - Historia Incognita. Attraktor Kiadó, Máriabesnyő - Gödöllő

Budai Napló, 1937-04-22 / 16. szám 6.

Budapest Városháza Fórum Tervpályázat, Müemlékvédelmi Tervfejezęt, 1. Letöltés: 2000.12.20. Web:

https:// static1.architectforum.hu/ files201 2/n00/01/12/00/muemlekitervfejezet.pdf

Carrieu, G. (2014): Les invalides du Consulat et de l'Empire, Histoire des Sciences Médicales, TOME XIVIII - N 3 - 2014, 317-326. o. Letöltés: 2021.03.19. Web: https://docplayer.fr/63275556-Histoiredes-sciences-medicales.html

Csetri E. (1999): „Katonának tött az átok” A katonáskodással szembeni ellenállás Erdélyben a francia és napóleoni háborúk idején (1792-1815), Hadtörténeti Közllemények, 1999, 4. sz. 1-34. Letöltés:

2021.03.19. Web: http:/ /epa.oszk.hu/00000/00018/00011 /pdf/csetri.pdf
Estók J. (2019): A büntetés-végrehajtás szervezetrendszerének alakulása a 19. század közepétől a 20. század végéig. Börtönügyi Szemle, 38. évf. 2019/1. sz., 951. o. Letöltés: 2021.03.19. Web: http:/ / epa.oszk.hu/02700/02705/00117 /pdf/EPA02705_bortonugyi_szemle_201 9_1_009-051.pdf

Hámori K. (2014): Georg Raphael Donner hatása a magyar szobrászatra. Doktori (PhD) disszertáció Eötvös Loránd Tudományegyetem Bölcsészettudományi Kar, Budapest 2014. Letöltés: 2021.03.19. Web:

http://doktori.btk.elte.hu/art/hamorikata lin/diss.pdf

Katonai ellátási törvény: 47-58. \$S, 99-105. SS

Kiss G. (2003): A Hadtörténelmi Levéltár

katona-egészségügyi iratainak repertóriuma 1740-1980, Hadtörténelmi Levéltár, Budapest. Letöltés: 2021.03.19. Web: http://vmek.oszk.hu/01400/01472/0147 2.pdf

Levéltári Szemle, 44. (1994) 1. szám, 40. o. Magyary-Kossa Gy. (1940): Magyar orvosi emlékelk. Értekezések a magyar orvostörténelem köréböl 4. Magyar orvostörténeti adattár (II.) (1700-1800). Magyar Orvosi Könyvkiadó Társulat, Budapest. Letöltés: 2021.03.19. Web: https://library.hungaricana.hu/hu/view/ KlasszikusOrvosiKonyvek_156/?pg=155 \&layout $=$ s\&query=invalidus

Megyery I. (1905): A magyar börtönügy és az. országos letartóztatási intézetek. Magyar Kir. Igazságügyministerium. Budapest, 1905. 11. o. 
Melly J. (1932): A hadigondozottak Budapesten. Budapesti Statisz̨tikai Közlemények $65 / 1$

Mezey B. (1993): Tömlöctartók: rokkant katonák, alacsony presztízs. Börtönügyi Szemle 12. évf. 4. sz. 51-57. letöltés: 2021.03.19. Web: https:/ / matarka.hu/cikk_list.php?fusz $=7$ 4953

Mezey B. (2018): A börtönügy a 17-19. században - $A$ börtön európai útja. Gondolat Kiadó, Budapest.

„Ministeri szervi határozvány” IV., Rendeleti Közlöny a Magyar Királyi Honvédség számára, 1883 17. szám, 26.

Molnár A. (1969): A Pesti Invalidus Ház avagy a városháza, Tükör - politikai és társadalmi hetilap, 47. szám 1969. 11. 25., 8-9.

Nagy L. (1975): Budapest Története 1686-1790 Budapest története III. A török kiüretéstöl a márciusi forradalomig. Akadémiai Kiadó, Budapest.

Net1. Letöltés: 2021.03.19. Web: http:/ / archive.monetarium.hu/invalidushaz-3-krajcar?search=invalidus

Net2. Koronaőr Alapítvány. Letöltés: 2021.03.19. Web: http://www.koronaoralapitvany.hu/cikke $\mathrm{k} /$ tortenet.html

Net3: A kööös hadsereg (hadi tengerészet) és a magyar királyi honvédség egyéneinek katonai ellátásáról sqóló 1875. évi LI. törvénycike. indokolása. Letöltés: 2021.03.19. Web: https:// net.jogtar.hu/ezer-evtorveny?docid $=87500051$. TVI\&searchUrl $=/$ ezer-evtorvenyei $\% 3$ Fpagenum\%3D43\#lbj0id4eb c
Ódor I. (1989): Baranya megye és a Napóleoni háborúk kori nemesi felkelések. A Baranya Megyei Levéltár évkönyve. Baranya Megyei Levéltár, Pécs, 1989, 77-79. o. Letöltés: 2021.03.19. Web: https:/ / matarka.hu/cikk_list.php?fusz $=5$ 1970

Pálmai A. (2012): A Magyar Királyi Koronaőrség 1944-1945. Rendvédelem-történeti Hirlevél XXI. évf. 37-38. szám, 212. o. Letöltés: 2021.03.19. Web: http://real.mtak.hu/104585/1/RTH_201 2_XXIevf_37-38sz_211-221p.pdf 212.

Pelz B. (1916): Rokkantellátás a hétéves háború után, Századok, 50. évf. 6. sz. 1916, 373-374.

Pezenhoffer A. (2004): A magyar nemzet történelme - A Katolikus Egyház és a Habsburg-ház történelmi szerepe. Történelmi Apologetika VIII. kötet, 314. Letöltés: 2021.03.19. Web: http://mek.oszk.hu/04200/04245/

Ráth-Végh I. (1977): Hatalom és Pénz: Gondolat Kiadó, Budapest.

Schoen A. (1930): A Budapesti Központi Városháza (volt Invalidus-Ház, majd Károly Kaszárnya). Budapest Székesfőváros Közönsége, Budapest.

Szoleczky E. (2001): A végelbocsátás jelképei, A Hadtörténeti Múzeum Értesitoojje Acta Musei Militaris in Hungaria 4. sz. 2001, 202-203.

Tamáska P. (1994): A magyarországi kórházak és szegényházak gazdálkodása a 18. század második felében. Levéltári Szemle, 44. (1994) 1. szám, 40. o.

Utasítás a közös hadsereg (haditengerészet) és a m. kir. honvédség egyéneinek katonai ellátásáról szóló 1875. évi LI. 
törvényczikk végrehajtása tárgyában, Rendeleti Közlöny a Magyar Királyi Honvédség számára, „A törv. cz. 99-ik §hoz", Rendeleti Közlöny a Magyar Királyi Honvédség számára, 1876 (3. évfolyam, 1. szám)

Weinhoffer J. (2017): A katona-egészségügy szerepe a rehabilitáció XX. száa adi fejlódésében. Doktori (PhD) értekezés, Nemzeti Közszolgálati Egyetem Hadtudományi Doktori Iskola, Budapest. Letöltés: 2021.03.19. Web: https:/ / doktori.hu/index.php?menuid=1 93\&lang=HU\&vid=17509

Závodi Sz. (2012): Életmód, életkörülmények és mentalitás a magyar

katonatisztcsaládoknál a 20. század első felében Doktori Disszertáció, Eötvös Loránd Tudományegyetem Bölcsészettudományi Kar, Budapest. Letöltés: 2021.03.19. Web: http://doktori.btk.elte.hu/hist/zavodiszil via/diss.pdf 61-64.
Takáts L. (2007): A Rákóczi-szabadságharc egészségügye. Semmelweis Orvostörténeti Múzeum, Könyvtár és Levéltár, valamint a Magyar Tudománytörténeti Intézet, Buda-pest. Letöltés: 2020.03.20. Web: https://mek.oszk.hu/05400/05419/

Wunder, B. (1984a): Die Institutionalisierung der Invaliden-, Alters- und Hinterbliebenenversorgung der Staatsbediensteten in Österreich (17481790). Mitteilungen des Instituts für Österreichissche Geschichtsforschung, 92, 1984, 343.

Wunder, B. (1984b): Die Institutionalisierung der Invaliden-, Alters und Hinterbliebenenversorgung der Staatsbediensteten in Österreich. Institut für Österreichische Geschichtsforschung, Mitteilungen; Innsbruck, 1984, 346. 